\title{
Peacekeeping: Resilience of an Idea
}

\author{
Mateja Peter
}

\section{INTRODUCTION}

Peacekeeping is not only one of the activities that the United Nations (UN) does, it is in many ways what the UN is. In countries emerging from the scourge of war, the acronym UN is customarily used as a synonym for the deployed peacekeeping operation. When member states, the public or the academics criticise the UN for not resolving conflicts, they not only talk of the political stalemates in the UN Security Council (UNSC, Council), but also invoke the failures of its peacekeeping missions. The significance of peacekeeping to member states is evident in financial terms: while the UN General Assembly agreed on a $\$ 5.4$ billion for the regular budget for the 2016-2017 biennium, ${ }^{1}$ the approved budget for UN peacekeeping operations for the fiscal year 1 July 2016-30 June 2017 was $\$ 7.87$ billion (UN 2016). Although UN peacekeeping still constitutes less than $0.5 \%$ of world military expenditures, ${ }^{2}$ it is the activity that the $\mathrm{UN}$ is most visibly associated with.

${ }^{1}$ The UN regular budget comes in two-year cycles (UN 2015a).

${ }^{2}$ http://www.un.org/en/peacekeeping/documents/factsheet.pdf.

\section{Peter $(\bowtie)$}

School of International Relations, University of St Andrews, St Andrews, UK e-mail: mp240@st-andrews.ac.uk

(C) The Author(s) 2019

C. de Coning and M. Peter (eds.), United Nations

Peace Operations in a Changing Global Order, https://doi.org/10.1007/978-3-319-99106-1_2 
UN peacekeeping is almost as old as the organisation itself. This chapter looks at the evolution of the idea of peacekeeping, asking how an instrument developed in the late 1940s managed to not only survive but also respond to the changing geopolitical and conflict landscape over the last seventy years. I do not plan to examine whether UN peacekeeping is the most appropriate response to conflicts emerging out of global fault lines. This would not only require an in-depth analysis of different conflicts, but I would even argue that in many respect the persistent reliance on UN peacekeeping is a result of a cognitive bias known as the law of the instrument: 'if the only tool you have is a hammer, you will treat everything as if it were a nail.' The UN Security Council has used this tool in 71 conflict situations, with 16 peacekeeping operations deployed at the time of writing. Evidently, member states have found peacekeeping useful. What I am primarily interested in here is the adaptation of the tool, examining for what purposes it has been used and why. I argue that peacekeeping started as a conflict management instrument, which was adapted to a conflict resolution mechanism after the end of the Cold War, but has now come full circle and is again increasingly used to manage and contain, not resolve conflicts. The strength of the idea comes from this resilience.

\section{Peacekeeping and the Cold War}

Despite their rapid importance for the identity of the organisation, the UN founders did not envisage peacekeeping operations as a tool for addressing conflicts. Peacekeeping is therefore not mentioned in the UN Charter (1945). According to the organisation's constitutive document, the UN Security Council, as the organ primarily responsible for the maintenance of international peace and security, could either take note of the threat to peace and security and recommend to conflict parties to resolve their dispute peacefully (Chapter VI) or it could take binding action to enforce measures to address the conflict by itself (Chapter VII). The Charter was devised to prevent the eruption of another world war. It ensured that great powers had a vested interest in the system designed to collectively punish a wrongdoer and set it on the right path (Kelsen 1948). In stark contrast to this, most conflicts in the subsequent years were tied to the processes of decolonialisation, where identifying the wrongdoer was not as clear cut. Throughout the Cold War, decolonialisation-related conflicts were also the only ones that the UNSC was 
willing to take up. As the Council was gridlocked, the only measures that could be adopted were in areas of secondary significance to the Union of Soviet Socialist Republics (USSR) and the United States (US). But even in these conflicts, enforcement measures were off the table. This was partly as these conflicts were mostly not as unambiguous to warrant clear enforcement measures, but primarily because great powers did not want to sanction an actor they could not entirely control-the UN-to use force. When coercive measures were deemed to be needed in their allied or client states, the two blocks employed them unilaterally. The core characteristics and principles of UN peacekeeping developed as a direct result of this Cold War schism. Peacekeeping emerged as a tool of necessity, sitting between Chapter VI and Chapter VII mandates.

The first UN peacekeeping missions were established already in 1948 and 1949. They signalled what kind of conflicts the UN would be preoccupied with in its first decades. The 1948 mission, the United Nations Truce Supervision Organization (UNTSO), was established following the conclusion of the first Arab-Israeli War (UN 1948). With it the UNSC sent a small number of unarmed military observers to monitor the ceasefire and report to the Council any violations. The mission had a similar mandate to the United Nations Military Observer Group in India and Pakistan (UNMOGIP) established a year later and tasked with monitoring the ceasefire of the Indo-Pakistani War of 1947-1948 (UN 1949). Both missions and conflicts share several characteristics. The conflicts erupted following recent declarations of independence. Israel declared statehood in 1947, as did both India and Pakistan. In the case of Israel, Arab states contested its statehood. India and Pakistan fought over a large border area of Kashmir and Jammu, both claiming it belonged to them. In both conflicts, the two Cold War rivals supported the opposing sides. $^{3}$ To ensure that the clash would not escalate and involve the US and the Soviet Union directly, a mechanism was devised to keep the sides separated. UN peacekeeping troops were tasked to monitor whether all sides were complying with the ceasefire and thus created a buffer zone between them. Peacekeepers had clear instructions not to get involved in internal affairs of the states and not to attempt to resolve conflicts. They were sent to manage these conflicts, not resolve them. Attempts

\footnotetext{
${ }^{3}$ India started openly cultivating strategic and military relations with the Soviet Union in the mid-1950s, after the US made Pakistan a Central Treaty Organisation ally. However, the split could be anticipated already in the late 1940s.
} 
at their resolution were taken up in other fora, both within and outside the UN. Indicating the intractability of both the Middle East and the Indo-Pakistani conflict, both missions are still in existence seven decades after. Compared to the post-Cold War operations, these are small enterprises (UNTSO is staffed by around 400 peacekeepers, including local staff; around 100 peacekeepers serve in UNMOGIP). Their continued presence speaks to the variety of conflicts that UN peacekeepers play a role in, as well as the coexistence of various peacekeeping models in the twenty-first century.

The first 'real' UN peacekeeping operation, which included armed military personnel, was sent to Egypt in 1956 following the Suez Crisis. The crisis erupted as Egypt was getting increasingly closer to the Soviet Union, which led to the withdrawal of US and UK support for the construction of the Aswan Dam. In turn, Egypt nationalised the Suez Canal. To regain Western control of this strategic trade route, Israeli, British, and French forces invaded Egypt. While the crisis was linked both to the decolonialisation and the Cold War power politics, it was also a clear act of aggression against a sovereign state. UK and French occupancy of the UNSC permanent seats meant that any proposed enforcement measures would have been immediately vetoed. But this time, the US and the Soviet Union had an interest in quickly resolving the crisis and through that also protect the collective security arrangements of the UN Charter. As political pressure from the two superpowers grew, all parties agreed that foreign forces should withdraw from the Egyptian territory and that their withdrawal should be overseen by a neutral force. This peacekeeping mission would then also serve as a buffer between the Egyptian and Israeli forces and provide impartial supervision of the ceasefire. The First United Nations Emergency Force (UNEF I) was in large measure a result of efforts by the UN Secretary-General Dag Hammarskjöld, who cobbled the mission together and obtained Egypt's consent for deployment of military personnel in its territory. The mission mandate was approved, not by the UNSC, but by the UN General Assembly (UN 1956). Importantly, peacekeepers were explicitly forbidden to interfere in internal matters of Egypt or undertake any activities that could influence the balance of power between conflicting parties. ${ }^{4}$ Again, the mission was to manage, not resolve, the conflict.

\footnotetext{
${ }^{4}$ For more on the mission, see Rosner (1964).
} 
Two years after the deployment of UNEF I, the Secretary-General published an extensive report summarising lessons learned from this first proper experience with UN peacekeeping, recommending a set of basic principles that should guide any future deployments. This was the first of the many times that initiatives in peacekeeping were developed and proposed by the central organ of the UN and not by the member states. The key principles of UN peacekeeping became consent, limited use of force, and non-interference in internal affairs of host states (UN 1958, pp. 154-193). The report stressed that for these missions to comply with international law and the UN Charter, "the United Nations cannot undertake to implement them by stationing units on the territory of a Member State without the consent of the Government concerned" (ibid., p. 155). Not limiting the authority of the UN to decide on the composition of the mission, the host government should also consent to the nationality of military troops deployed. Hammarskjöld envisaged this would not include contingents from permanent members of the UNSC or regional countries that might have a special interest in the situation, thus ensuring impartiality of the operation (ibid., p. 160). ${ }^{5}$ The report also underlined that authority granted to a UN mission could not be exercised in competition with the host government or in cooperation with it through a joint deployment. It concluded that "a United Nations operation must be separate and distinct from activities by national authorities" (ibid., p. 165) and "cannot be permitted in any sense to be a party to internal conflicts" (ibid., p. 166). Any intervention in internal affairs of a host state would not only make the peacekeeping mandate more difficult to achieve but could also negatively impact relations between the UN and its member state.

Consent, limited use of force, and non-interference in internal affairs of host states became the bedrock for UN peacekeeping interventions throughout the Cold War. While proposed by the UN SecretaryGeneral, his ambition was limited by what the two great powers allowed the UN to develop. For the first forty years, UN peacekeeping essentially meant observation of ceasefires in inter-state disputes. That notwithstanding, the organisation launched two operations that signalled where UN peacekeeping would develop after the bipolar order had

\footnotetext{
${ }^{5}$ In the case of UNEF I, contingents came from ten countries: Brazil, Canada, Colombia, Denmark, Finland, India, Indonesia, Norway, Sweden, and Yugoslavia.
} 
collapsed. These missions also indicate that the type of conflicts we tend to associate with the post-Cold War order, predate its collapse.

The first operation to stray from the typical Cold War peacekeeping model was deployed in 1960 to the former Belgian colony of Congo, the modern day Democratic Republic of the Congo (Congo). ${ }^{6}$ The United Nations Operation in Congo (Opération des Nations Unies au Congo, ONUC) is to this day one of the largest UN peacekeeping operations to be deployed and at its height counted almost 20,000 armed troops. ${ }^{7}$ It is also the first peacekeeping mission, which due to developments on the ground, ended up intervening into a civil war. The original mandate of the operation was in line with Hammarskjöld's vision as the mission was supposed to supervise the withdrawal of Belgian colonial forces from the Congolese territory (UN 1960). ONUC was set up to help the newly independent country stabilise the situation on the ground and pave the way for the new government. Instead, peacekeepers became caught up in an armed conflict between two groups of warring factions supported by the USSR and the US. While the UNSC agreed to a strengthened mandate in 1961 (UN 1961), ONUC could not resolve the crisis which grew into a series of civil wars. But the mission was influential for the development of UN peacekeeping. Besides being the first operation to intervene in an intra-state conflict, it was also the first mission where the UNSC authorised the use of force for purposes beyond self-defence. At the time, there were disagreements over what that meant in practice. The issue was far from resolved, but the debate itself foreshadowed the difficulties with strict adherence to the peacekeeping principles that peacekeeping missions face today in intra-state conflicts (Gibbs 2000; Spooner 2010).

The second atypical peacekeeping operation during the Cold War was the United Nations Security Force in West New Guinea (UNSF). UNSF was authorised by the UN General Assembly to administer the territory of West New Guinea between October 1962 and April 1963 (UN 1962). After that period this former Dutch colony became part of Indonesia.

\footnotetext{
${ }^{6}$ In 1960, the former colony declared independence as the Republic of Congo. The country changed its name to the Democratic Republic of Congo in 1964.

${ }^{7}$ The current operation in the DRC (MONUSCO) is also the largest peacekeeping operation at the time of writing. Its strength in October 2017 was over 21,000 uniformed and civilian personnel. See: https://peacekeeping.un.org/en/peacekeeping-fact-sheetoct-2017. More on MONUSCO below.
} 
In the context of the Cold War any administration of the territory by a peacekeeping force was almost unimaginable, but UNSF represented a viable compromise for a resolution of a long-standing dispute between Indonesia and the Netherlands. As Indonesia grew increasingly close to the USSR, the US obtained the Dutch agreement to the Indonesian claim in exchange for Indonesian support of the Western bloc. To preserve the Dutch dignity, the territory was not to be handed over to the Indonesians directly, but to the UN peacekeepers, who ended up managing it for over half a year. ${ }^{8}$ While both ONUC and UNSF sowed the seeds for what UN peacekeeping would look like after the end of the Cold War, for the first forty years peacekeeping was largely contained to supervising ceasefires. It was only with dramatic global changes that these missions could develop into what they are known for today.

\section{End of the Cold War and the New UN Peacekeeping}

The fall of the Berlin Wall presented a tectonic change in how the UNSC and member states of the UN responded to conflicts. Not only was there more cooperation between the Cold War rivals on the Security Council, but many states came under increasing pressure from their constituencies to address human plight in far-flung places. Globalisation and the 24-hour news cycles brought these conflicts to the attention of audiences in the global North. During the last years of the Cold War, the two superpowers also showed much less interest in directly addressing problems of and within their allied and client states. They relinquished a bulk of this task to international organisations, most notably the United Nations. This lead to a boom in international peacekeeping, with 58 out of a total of 71 UN missions established after $1988 .{ }^{9}$ But the change was not only quantitative. These new missions, often referred to as second generation peacekeeping (Mackinlay and Chopra 1993), also changed qualitatively. A small number of post-1988 missions-for example, the United Nations Good Offices Mission in Afghanistan and Pakistan (UNGOMAP), which supervised the withdrawal of Soviet troops from Afghanistan and Pakistan (UN 1988)—retained their traditional mandates, but most operations substantially gained in complexity receiving

\footnotetext{
${ }^{8}$ More on the background of the mission at https://peacekeeping.un.org/mission/ past/unsf.htm.

${ }^{9}$ https://peacekeeping.un.org/en/past-peacekeeping-operations.
} 
mandates addressing internal matters of sovereign states. This was a brand-new experience for the UN.

The first group of these multi-dimensional missions, established between 1988 and 1992, preserved some of the characteristics of the Cold War monitoring missions. The main difference was that these new missions were primarily tasked with monitoring non-military activities. The United Nations Transition Assistance Group (UNTAG) was mandated to ensure the early independence of Namibia through free and fair elections (UN 1989). Its police component was tasked with monitoring and reporting on the actions of local police and security forces. UNTAG also helped with monitoring and assisting in the return of refugees. UN peacekeeping operations in El Salvador, Angola, Western Sahara, Cambodia, and Mozambique were similarly tasked with observing elections, reporting on human rights violations and the establishment of a basic post-war rule of law. While these tasks are a common feature of any UN mission deployed in the twenty-first century, at the time, they were nothing less but revolutionary. Peacekeepers were no longer being sent into troubled territories to monitor inter-state disputes, but primarily dealt with intra-state conflicts. Moreover, peacekeeping now meant not only the deployment of military troops, but also of a civilian and a police component, leading eventually to the establishment of the United Nations Office of Rule of Law and Security Institutions (OROLSI).

These early multidimensional peacekeeping attempts have been judged as largely successful by both the UN and outside experts (Howard 2007). They did nonetheless present a challenge for the peacekeeping principles proposed by Hammarskjöld as the UN had to adapt to the new geopolitical and conflict environment. The 1992 document An Agenda for Peace, prepared by the UN Secretary-General Boutros Boutros-Ghali, foreshadowed some of these challenges but maintained that "the established principles and practices of peace-keeping have responded flexibly to new demands of recent years" and that "the basic conditions for success remain unchanged" (UN 1992, para. 50). Highlighting the increasing number of tasks given to UN peacekeepers by the Security Council, the report nonetheless drew sharp lines between peacekeeping, peace enforcement, and peacebuilding. ${ }^{10}$ As early as 1992, the Secretary-General and his advisers were acutely aware of complications that could emerge if the concept

\footnotetext{
${ }^{10}$ See the introduction of this volume for distinctions between the three.
} 
of peacekeeping was stretched into peace enforcement. The document therefore urged the UNSC that when fighting resumed and ceasefires were broken, peace enforcement units should be utilised. Such units would be more heavily armed than peacekeepers and would be mandated to use force beyond self-defence (UN 1992, para. 44).

While distinctions between peacekeeping and peace enforcement were drawn sharp on paper, in practice, the UNSC increasingly deployed peacekeeping missions into situations where peace was extremely fragile. The two most notorious of these missions were based in Rwanda (United Nations Assistance Mission for Rwanda, UNAMIR) and Bosnia and Herzegovina (United Nations Protection Force, UNPROFOR), where peacekeepers were deployed amid genocidal wars. The ongoing fighting and ethnic cleansing created substantial confusion among UN troops, who were worried not just about overstepping their mandates but also about getting involved in civil wars. They interpreted peacekeeping principles narrowly and as a result failed to use force to protect civilian population. Srebrenica and Rwanda to this day serve as poignant reminders of the failures of UN peacekeeping and the UN system to act on evolving genocides. The UNSC became more willing to deploy peacekeepers to civil wars, but these early post-Cold War mistakes highlighted that willingness to deploy is not enough; peacekeeping would need to adapt if it was to remain a useful tool.

\section{Rethinking UN Peacekeeping for the Post-Cold War Era}

The gravity of these failures created an opportunity for a deeper reflection on the role of the organisation in the post-Cold War order (Barnett 2002; Malone and Thakur 2001; Western 2002). In 1999, the SecretaryGeneral Kofi Annan appointed an independent Panel on United Nations Peace Operations, asking it to address the shortcomings of existing peace operations system and to make realistic recommendations for their future. Notwithstanding the recent crises, the Brahimi report (UN 2000), named after the chair of the panel, called for a renewed political commitment to UN peace operations. Most of the report deals with the increasing complexity of conflicts that peacekeeping operations have been mandated to address since the end of the Cold War. Many of its core findings remain relevant to this day, despite it being created at the time of undisputed Western hegemony. 
UN peacekeeping operations had only a limited experience in peacebuilding when the report was written, but the trend towards longerterm peacebuilding mandates was already visible. The Brahimi report therefore aptly noted that as peacekeeping operations took on more peacebuilding tasks, their mandates would become more difficult to accomplish (UN 2000, paras. 19-20). Unlike early experiences of peacekeeping, where operations had been deployed to manage conflicts, the post-1995 operations were being deployed with an objective to help countries resolve their conflicts. Mandates of missions from Bosnia and Herzegovina to Haiti and Sierra Leone asked peacekeepers to help with reforms of the rule of law and security sector in addition to the more traditional monitoring tasks of earlier missions. Such peacekeeping missions were becoming pieces of a broader (liberal) statebuilding agenda (Fukuyama 2004; Paris 2004; Richmond 2004). UN peacekeepers, together with regional organisations and international financial institutions, which focused more on the economic aspects, were asked to build basic institutional structures and assist states in establishing post-conflict functionality and legitimacy. More stable institutions were seen as a precondition for peace. In the most extreme cases - in Kosovo and in Timor-Leste-UN peacekeepers were even given a temporary executive law enforcement and administrative authority over a territory (UN 1999a, b; Caplan 2005; Chesterman 2005). Such conflict resolution mandates were undeniably a more ambitious task than conflict management undertakings of earlier missions.

Peacekeeping operations started growing, and complexity necessitated a discussion on the coherence of international approaches to conflicts. If different parts were acting at cross-purposes, less could be achieved. The Brahimi report asked for establishment of Integrated Mission Task Forces at the level of UN headquarters. These entities would substitute the ad hoc coordination activities and would mirror the various functions of the missions themselves. They would be responsible for mission-specific planning and would act as a coordination group for all UN departments involved (UN 2000, paras. 198-217). Over the next decade, the UN launched a series of initiatives expanding on this thinking. These initiatives aimed to ensure more coherence of UN action. Most notable of these were the introduction of UN Integrated Missions in 2006 (UN 2006), which then developed into a broader UN Integrated Approach in 2008, which is still in place today (UN 2008a). Yet despite these innovations, many of these new multi-dimensional operations saw less success in the implementation of their mandates than the early-era peacekeeping. 
The Brahimi report also reiterated the stark distinction between peace enforcement and peacekeeping found in earlier documents. The panel recognised that "the United Nations does not wage war" (UN 2000, para. 53) and urged the UNSC to entrust enforcement actions to coalitions of willing states. It maintained that "consent of the local parties, impartiality and use of force only in self-defence should remain the bedrock principles of peacekeeping" (UN 2000, para. 48). But despite this strong and unambiguous language, strict adherence to these principles was virtually impossible to maintain (de Coning et al. 2017). This became even more pronounced from mid-2000s on, when the UNSC started deploying operations with explicit mandates to protect civilians (Holt and Taylor 2009). The Capstone doctrine from 2008, which to this day provides guidance for modern UN-led peacekeeping operations, tried to clarify some of the ambiguity over how peacekeeping principles should be interpreted. Its guidance explained that "impartiality ... should not be confused with neutrality or inactivity," and that "a peacekeeping operation should not condone actions by the parties that violate the undertakings of the peace process or the international norms and principles" (UN 2008b, p. 33). But in practice things were murkier as troop contributing countries and mission leadership were often reluctant to use force robustly, worrying about casualties and about getting involved in civil wars. ${ }^{11}$

The experience with the United Nations Mission in the Republic of South Sudan (UNMISS) demonstrates how swiftly missions need to adapt in contemporary conflicts and what challenges they face when protecting civilians. UNMISS was established in 2011 (UN 2011) and was simultaneously mandated to support the government of South Sudan in establishing the institutions necessary to govern a new country and to hold it accountable to international norms and standards (da Costa and Peter 2017). Reconciling the two was difficult from the beginning, but as political wrangling between President Kiir and Vice-President Machar escalated, the newly independent country descendent into a civil war. UNMISS was now caught between a rock and a hard place, mandated to help the government which was swiftly becoming the biggest threat to its own population. While the UNSC changed the mandate to a protection of civilians one (UN 2014a), and the mission became more proactive in

\footnotetext{
${ }^{11}$ For more on the use of force in UN peacekeeping see Mats Berdal in this volume.
} 
protecting civilians, including by opening the gates of its compounds, ${ }^{12}$ problems remained. The mission was not perceived as impartial by the warring parties, which repeatedly threatened to withdraw their consent to UN presence. At the same time "a de facto dual line of command involving mission leadership and troop-contributing countries that regulates the use of force by missions" (UN 2014b), meant that peacekeeping contingents were not intervening when civilians were under attack.

The High-Level Independent Panel on Peace Operations Report (HIPPO report) identified protection of civilians as "a core obligation of the United Nations" (UN 2015b, p. ix). This requirement is also explicitly included in the great majority of mandates of current missions. While this emphasis is not revolutionary-UN reports dating back to the early 2000s have been stressing protection of civilians as a core function of UN peacekeeping - the need for protecting vulnerable populations has never been so high. Protecting civilians, as imperfectly as it is implemented, is what both the local population and the international community expect of UN peacekeeping today. But while this normative change is essential for the credibility of the $\mathrm{UN}$, it also means that the nature of peacekeeping is changing. As more mandates switch from peacebuilding/statebuilding ones to what is essentially an emergency humanitarian peacekeeping, newly deployed peacekeeping operations are increasingly moving away from a conflict resolution to a conflict management tool.

\section{A New Era of Enforcement Peacekeeping?}

Peacekeeping has undergone substantial changes over the last decade and these operations are now firmly moving away from conflict resolution to conflict management. Protection of civilians is and will remain the core challenge if the UN as an institution wants to retain its credibility in the twenty-first century. At the same time, we are seeing a new trend in the kind of operations the Council is mandating. After a short period of seeming decline in large-scale operations, the UNSC has since 2013 become more comfortable authorising larger operations. In addition to the Democratic Republic of the Congo (DRC) mission, which was strengthened with additional forces and amounts to over 22,000 troops, the Council authorised a deployment of 12,000 troops and police to

\footnotetext{
${ }^{12}$ See Hilde Frafjord Johnson in this volume for more on how the mission was adapting to include the protection of civilians mandate.
} 
Mali and 10,000 to the Central African Republic (CAR) (UN 2013a, $2014 \mathrm{c}$ ). More importantly for the idea of peacekeeping itself, the types of activities that these new missions and the newly enhanced missions are mandated to perform substantially expand and change the nature of UN peacekeeping. Peacekeeping operations deployed to the DRC, Mali, and the CAR operate in midst of open conflicts, in the first two cases no comprehensive peace agreement had been negotiated before missions were deployed. In the past, both the Secretariat and the UNSC were reluctant to deploy under such circumstances, but that seems to be changing. As a result, these operations actively borrow elements from peace enforcement missions, walking the line between peacekeeping and peace enforcement. After traditional and multidimensional peacekeeping, we are on the cusp of a new era of enforcement peacekeeping. This introduces a possible new type of peacekeeping operations, which will end up coexisting with previous types of peacekeeping.

Enforcement peacekeeping manifests itself through two inter-related developments: (a) in enforcement of political solutions through support of a government's state-building ambitions in its attempts to extend state authority amid an ongoing conflict, and (b) in enforcement of military victories through offensive use of force. ${ }^{13}$ As targets of peacekeeping actions are non-state actors that enjoy little international legitimacy due to their appalling human rights and war crimes records, no comprehensive peace agreements with them are sought before peacekeepers are deployed, something that is in stark contrast with multidimensional peacekeeping developed after the end of the Cold War.

The most noticeable and talked about mission in this regard has been the UN Organization Stabilization Mission in the Democratic Republic of the Congo (MONUSCO). To MONUSCO, the Security Council authorised the inclusion of a force intervention brigade (FIB) within an existing mission structure (UN 2013b). This is the "first-ever 'offensive' combat force" in UN peacekeeping (UN 2013c), which was set-up to "neutralize and disarm" - a euphemism used by the military when engaging in offensive operations - the Tutsi March 23 (M23) militia in the eastern parts of the DRC. FIB is mandated to assist Congolese forces in fighting all armed groups in the Eastern Congo, with a few of them explicitly listed in the UNSC resolution. This was the first time in the history

\footnotetext{
${ }^{13}$ For more details on enforcement peacekeeping discussed in this section, see Peter (2015).
} 
of UN peacekeeping that the Council created a list of enemies that UN peacekeepers were supposed to engage with, making some researchers wonder whether the UN now wages war (Karlsrud 2015).

Although the Congolese experience has not been entirely replicated in other missions so far, it does indicate a wider trend towards more robust UN operations, opening doors for offensive use of force. For example, the United Nations Multidimensional Integrated Stabilization Mission in Mali (MINUSMA) (UN 2013a) assimilated an extant Economic Community of West African States (ECOWAS) mission named AFISMA, which was previously mandated to support the government of Mali, an ECOWAS member nation, in its fight against Islamist rebels in the northern Mali conflict. The resolution establishing MINUSMA also authorised French troops conducting Operation Serval to use all necessary means to intervene within the limits of their capacities and areas of deployment in support of elements of MINUSMA, essentially mandating an intervention brigade just outside the UN command structures. UN missions are, as these examples indicate, increasingly more robust.

One good indication of increasing involvement of UN peacekeepers in enforcement of political and military solutions can be found in the types of capabilities that these missions are relying on. The UN has advocated for the use of surveillance drones in the eastern DRC, on the border between Côte d'Ivoire and Liberia, in South Sudan, and in Mali. In Somalia, the UN is engaged in strategic communication campaigning and has hired a consultancy firm that, according to its statements, "runs a fully integrated campaign to counter the radicalising effect of Al-Shabaab and engage Somalis in building a positive future for their country" (Albany Associates 2017). In Mali, peacekeepers have been openly relying on strategic intelligence in their engagement with Islamic rebels. In 2000, when the Brahimi report suggested incorporation of field intelligence in peace operations so that they could better respond to complex situations (UN 2000, para. 51), member states flat out rejected the proposals. A good decade later their outlooks have changed. Drones, intelligence, and strategic communication all evoke ideas of stabilisation missions in Iraq and Afghanistan. The major difference is that the UN peacekeeping activities are conducted on request of governments in target states.

As mandates change, we are also seeing a change in the composition of troops in UN peacekeeping. UN operations increasingly rely on regional contributions, as only highly interested states are willing to risk the lives 
of their citizens in increasingly robust operations. When Hammarskjöld penned the peacekeeping principles in the 1950s, this would have been unheard of. A prime example of this development is MINUSMA, which by incorporating AFISMA became ostensibly a mission composed of regional troops. Among the top five troop contributors to the Mali mission in October 2017 were Burkina Faso, Chad, Senegal, and Togo, all regional states. ${ }^{14}$ In the DRC, the primary contributors to the intervention brigade are South Africa, Tanzania, and Malawi, while the rest of the MONUSCO mission is composed mainly of South Asian troops. Inclusion of regional forces has already flagged up some problems in the CAR, where Chadian forces needed to be redeployed due to Chad's perceived backing of the Muslim rebel group Séléka, which led the coup against the CAR government (Al Jazeera 2013).

The switch towards more robust operations has several implications on peacekeeping principles and broader UN peacebuilding attempts (Peter 2015; Hunt 2017; de Coning et al. 2017). Most important for the argument in this chapter, is that these missions are abandoning their conflict resolution ambitions, focusing only on the management and containment of these conflicts. But unlike the Cold War peacekeeping operations, which similarly focused on conflict management, the new missions are actively siding with the often-contested governments. When UN peacekeepers side with one party in a conflict, whether by helping it extend state authority or defeat enemy combatants, this substantially affects the conflict and political dynamics at that time. As political reincarnations of these same armed groups will in many cases need to be included in peace settlements for these to become sustainable, this will have far-reaching consequences for the UN's ability to act as an impartial broker in peace processes.

These new UN attempts to manage conflicts could have negative implications on UN's ability to contribute to conflict resolution. It is therefore unsurprising that UN reports, including the report of the HIPPO panel, convey discomfort with the idea of robust enforcement peacekeeping. The big question for the future is whether the UN as an institution will be able to resist the pressures from member states to morph peacekeeping with peace enforcement.

${ }^{14}$ See: https://peacekeeping.un.org/en/mission/minusma. 


\section{Conclusions}

The history of UN peacekeeping almost serves as a history of the types of conflicts that the international community has been dealing with since the end of the Second World War. It also reminds us how the peacekeeping tool was adapted from a bipolar world, via a unipolar one to today's multipolar world. In many ways, it is remarkable that an instrument developed in the immediate aftermath of the Second World War managed to survive so long. Blue helmets are a poignant symbol of conflict interventions over the last seventy years. But we should also be cognisant that the label of peacekeeping has encompassed very different activities over this period. While the UN maintains that the core principles-consent, impartiality, and the non-use of force-developed in the 1950s remain relevant today, these principles have changed substantially as missions evolved. Peacekeeping today bears only casual resemblance to peacekeeping from decades ago.

In one respect, however, the UN is returning to its roots. Peacekeeping started as a conflict management tool, aiming to keep warring states at bay. It was an instrument designed to facilitate de-escalation of conflicts, or at minimum to curb their escalation. With the end of the Cold War, the UN and its member states adapted this tool for conflict resolution purposes, aiming to help states deal with their internal struggles. This was primarily a reflection of the newly found consensus within the UNSC that came with the Western hegemony in global institutions. Peacebuilding through statebuilding became the agenda. The scholarly community is split over how successful these attempts have been and whether it is even desirable for the UN to get involved in the domestic affairs of post-conflict states. But these debates seem somehow outdated at the time when most new UN missions are either tasked with the protection of civilians or are adopting peace enforcement elements. While such operations are designed to respond to contemporary conflicts, they have all but abandoned any conflict resolution ambitions. Contemporary operations are deployed to manage and contain the conflicts they are addressing, countering pressures from non-state actors on the state system. With that, UN peacekeeping has come full circle as it is again used as a tool to curb escalation of local and regional conflicts into bigger problems for the international system. And in this ability to adapt to the needs of the states lies the resilience of the idea of peacekeeping itself. 


\section{REFERENCES}

Al Jazeera. 2013. Chad Troops in CAR Accused of Pro-Seleka Bias. Al Jazeera, December 26. http://www.aljazeera.com/news/africa/2013/12/chad-troopscar-accused-pro-seleka-bias-201312261218569193.html. Accessed 19 Dec 2017.

Albany Associates. 2017. Somalia: AU/UN Information Support. www.albanyassociates.com/projects/somalia. Accessed 19 Dec 2017.

Barnett, Michael. 2002. Eyewitness to a Genocide. Ithaca and London: Cornell University Press.

Caplan, Richard. 2005. International Governance of War-Torn Territories: Rule and Reconstruction. Oxford: Oxford University Press.

Chesterman, Simon. 2005. You, the People: The United Nations, Transitional Administration, and State-Building. Oxford: Oxford University Press.

da Costa, Diana Felix, and Mateja Peter. 2017. UN Support in the Formation of New States: South Sudan, Kosovo and Timor-Leste. In UN Peacekeeping Doctrine Towards in a New Era: Adapting to Stabilisation, Protection and New Threats, ed. Cedric de Coning, Chiyuki Aoi, and John Karlsrud, 189-210. Abingdon, Oxon: Routledge.

de Coning, Cedric, Chiyuki Aoi, and John Karlsrud (eds.). 2017. UN Peacekeeping Doctrine Towards in a New Era: Adapting to Stabilisation, Protection and New Threats. Abingdon, Oxon: Routledge.

Fukuyama, Francis. 2004. State-Building: Governance and World Order in the $21 s t$ Century. Ithaca: Cornell University Press.

Gibbs, David N. 2000. The United Nations, International Peacekeeping and the Question of 'Impartiality': Revisiting the Congo Operation of 1960. The Journal of Modern African Studies 38 (3): 359-382.

Holt, Victoria, and Glyn Taylor. 2009. Protecting Civilians in the Context of UN Peacekeeping Operations. Successes, Setbacks and Remaining Challenges. Independent Study. New York: UN Department of Peacekeeping Operations and Office for the Coordination of Humanitarian Affairs.

Howard, Lise Morje. 2007. UN Peacekeeping in Civil Wars. Cambridge: Cambridge University Press.

Hunt, Charles T. 2017. All Necessary Means to What Ends? The Unintended Consequences of the 'Robust Turn' in UN Peace Operations. International Peacekeeping 24 (1): 108-131.

Karlsrud, John. 2015. The UN at War: Examining the Consequences of PeaceEnforcement Mandates for the UN Peacekeeping Operations in the CAR, the DRC and Mali. Third World Quarterly 36 (1): 40-54.

Kelsen, Hans. 1948. Collective Security and Collective Self-Defence Under the Charter of the United Nations. American Journal of International Law 42 (4): 783-796.

Mackinlay, John, and Jarat Chopra. 1993. A Draft Concept of Second Generation Multinational Operations. Providence: Watson Institute. 
Malone, David M., and Ramesh Thakur. 2001. UN Peacekeeping: Lessons Learned? Global Governance 7 (1): 11-17.

Paris, Roland. 2004. At War's End: Building Peace after Civil Conflict. Cambridge: Cambridge University Press.

Peter, Mateja. 2015. Between Doctrine and Practice: The United Nations Peacekeeping Dilemma. Global Governance 21 (3): 351-370.

Richmond, Oliver P. 2004. UN Peace Operations and the Dilemmas of the Peacebuilding Consensus. International Peacekeeping 11 (1): 83-101.

Rosner, Gabriella. 1964. The United Nations Emergency Force. New York: Columbia University Press.

Spooner, Kevin A. 2010. Canada, the Congo Crisis, and UN Peacekeeping, 1960-64. Vancouver: UBC Press.

The Charter of the United Nations, signed in San Francisco on 26 June 1945, came into force on 24 October 1945.

United Nations. 1948. United Nations Security Council Resolution 50. New York: United Nations.

United Nations. 1949. United Nations Security Council Resolution 90. New York: United Nations.

United Nations. 1956. United Nations General Assembly Resolution 1001 (ES-I). New York: United Nations.

United Nations. 1958. Report of the Secretary General: Summary Study of the Experience Derived from the Establishment and Operation of the Force, October 9. New York: United Nations.

United Nations. 1960. United Nations Security Council Resolution 143. New York: United Nations.

United Nations. 1961. United Nations Security Council Resolution 161. New York: United Nations.

United Nations. 1962. United Nations General Assembly Resolution 1752. New York: United Nations.

United Nations. 1988. United Nations Security Council Resolution 622. New York: United Nations.

United Nations. 1989. United Nations Security Council Resolution 632. New York: United Nations.

United Nations. 1992. An Agenda for Peace, Preventive Diplomacy, Peacemaking and Peace-Keeping: Report of the Secretary-General pursuant to the statement adopted by the Summit Meeting of the Security Council on 31 January. New York: United Nations.

United Nations. 1999a. United Nations Security Council Resolution 1244. New York: United Nations.

United Nations. 1999b. United Nations Security Council Resolution 1272. New York: United Nations.

United Nations. 2000. Report of the Panel on United Nations Peace Operations. New York: United Nations. 
United Nations. 2006. Integrated Missions Planning Process (IMPP), Guidelines Endorsed by the Secretary-General 13 June 2006. New York: United Nations.

United Nations. 2008a. Decision Number 2008/24-Integration, Decisions of the Secretary-General, 25 June 2008, Policy Committee. New York: United Nations.

United Nations. 2008b. United Nations Peacekeeping: Principles and Guidelines (Capstone Doctrine). New York: UN Department of Peacekeeping Operations.

United Nations. 2011. United Nations Security Council Resolution 1996. New York: United Nations.

United Nations. 2013a. United Nations Security Council Resolution 2100. New York: United Nations.

United Nations. 2013b. United Nations Security Council Resolution 2098. New York: United Nations.

United Nations. 2013c. 'Intervention Brigade' Authorized as Security Council Grants Mandate Renewal for United Nations Mission in Democratic Republic of Congo. UN News, press release, March 28, New York.

United Nations. 2014a. United Nations Security Council Resolution 2155. New York: United Nations.

United Nations. 2014b. Report of the Office of Internal Oversight Services. Evaluation of the Implementation and Results of Protection of Civilians Mandates in United Nations Peacekeeping Operations. New York: United Nations Office of Internal Oversight Services.

United Nations. 2014c. United Nations Security Council Resolution 2149. New York: United Nations.

United Nations. 2015a. Fifth Committee Recommends \$5.4 Billion Budget for 2016-2017 Biennium as It Concludes Main Part of Seventieth Session. https://www.un.org/press/en/2015/gaab4185.doc.htm.

United Nations. 2015b. Report of the High-Level Independent Panel on Peace Operations on Uniting Our Strengths for Peace: Politics, Partnership and People. New York: United Nations.

United Nations. 2016. UN General Assembly, Approved Resources for Peacekeeping Operations for the Period from 1 July 2016 to 30 June 2017, June 22 , A/C.5/70/24.

Western, Jon. 2002. Sources of Humanitarian Intervention: Beliefs, Information, and Advocacy in the U.S. Decisions on Somalia and Bosnia. International Security 26 (4): 112-142. 
Open Access This chapter is licensed under the terms of the Creative Commons Attribution 4.0 International License (http://creativecommons.org/licenses/ by $/ 4.0 /$ ), which permits use, sharing, adaptation, distribution and reproduction in any medium or format, as long as you give appropriate credit to the original author(s) and the source, provide a link to the Creative Commons license and indicate if changes were made.

The images or other third party material in this chapter are included in the chapter's Creative Commons license, unless indicated otherwise in a credit line to the material. If material is not included in the chapter's Creative Commons license and your intended use is not permitted by statutory regulation or exceeds the permitted use, you will need to obtain permission directly from the copyright holder.

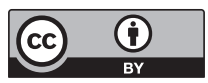

